\title{
DO SMES FACE A HIGHER TAX BURDEN? EVIDENCE \\ FROM BELGIAN TAX RETURN DATA
}

\section{Pieter Buyl, Annelies Roggeman*}

\begin{abstract}
The public debate on taxation of domestic small and medium enterprises (SMEs) versus large and multinational enterprises (MNEs) is highly relevant nowadays. Using confidential tax return data instead of financial statement data, the results indicate that domestic SMEs face on average a 1.6 and 4.8 percentage-point higher effective tax burden compared to large domestic and large MNEs respectively. This suggests that tax incentives for SMEs are inadequate to compensate for the tax advantages of large and internationally operating companies. Furthermore, we show that the use of information built exclusively upon accounting data could bias the results.
\end{abstract}

Keywords: corporate tax return data, SMEs, effective tax burden, reduced tax rates JEL Classification: F23, H25, H26

\section{Introduction}

In the aftermath of the financial crisis and the subsequent economic downturn, tax avoidance techniques (e.g., transfer pricing) by multinational enterprises (MNEs) have come under scrutiny by tax administrations, tax experts and the general public (European Commission, 2015). It is argued that MNEs' aggressive tax avoidance techniques lead to internal market distortions and higher effective tax burdens for smaller firms, which primarily operate domestically (European Commission, 2016a). ${ }^{1}$

Current literature especially focuses on tax burden differences between large MNEs and large domestic firms (e.g., Dyreng et al., 2017), or often limits itself to measuring the impact of size in general, without a more accurate classification for SMEs (e.g., Gupta and Newberry, 1997; Richardson and Lanis, 2007; Onofrei et al., 2018). Moreover, smaller firms are often left out because a certain threshold is applied due to data constraints (e.g., Janssen, 2005; Vandenbussche et al., 2006). This is unfortunate, as SMEs make an important contribution to employment, job creation and innovation (OECD, 2015).

One of the exceptions is the study by the European Commission (2015), in which the effective average tax rate for cross-border investments of large multinationals is compared to the effective tax rates of SMEs operating on domestic markets. Applying the DevereuxGriffith methodology (1999), the results for Belgium show that, when taking into account

Pieter Buyl, Ghent University, Corporate Finance and Taxation, Ghent, Belgium (pieter.buyl@ugent.be); Annelies Roggeman, Ghent University, Corporate Finance and Taxation, Ghent, Belgium (annelies. roggeman@ugent.be).

1 In line with the European Commission, we define aggressive tax avoidance strategies as strategies that fall within the limits of the law, but go against the spirit of the law. 
SME incentives for 2013, SMEs face a lower effective tax rate (18.7\%) compared to large MNEs (24\%). Despite the merits of the Devereux-Griffith model, the computations reflect a model investment rather than a model corporation and several assumptions are made with respect to the assets, finance and shareholder structure of the investment company (Devereux and Griffith, 1999).

Applying the European Tax Analyzer (ETA), Bergner et al. (2017) assess the average tax burden for SMEs and large companies in the EU member states. Generally, they find that the majority of tax incentives in the EU do not have a significant impact on the tax burden of SMEs. For Belgium specifically, isolating the impact of SME tax incentives (e.g., reduced tax rates), leads to a reduction in the (absolute) effective tax burden by $2.37 \%$ for Belgian SMEs. A disadvantage of the study by Bergner et al. (2017), however, is its limitation to domestic markets. Moreover, the ETA simulates the tax burden of a "typical SME or large company" which is defined as an average company on the basis of financial statement data contained in the Amadeus database. Several estimates and assumptions are required to define this average model firm, which makes the results dependent on the specific characteristics of the model firm.

Also a number of other European studies exclusively rely on accounting data to determine the effective tax burden. Using data from the Amadeus database for 21 European countries between 1992 and 2004, Nicodème (2007) investigates whether large firms would have lower ETRs compared to SMEs. In all the countries, the number of employees is negatively related with ETRs. The total assets are positively related with ETRs, but the results are not robust across countries. As the study only includes companies with more than EUR 10 million operating revenues, EUR 20 million assets and 100 employees, smaller firms are left out of consideration.

Also Jaafar and Thornton (2015) examine ETRs based on the Amadeus database and consider 14 countries in the period 2001-2008. In particular, they assess the impact of tax havens on the effective tax burdens of private and publicly listed firms. The results indicate that tax avoidance by means of tax havens leads to lower ETRs, and that this is more pronounced for privately held firms. When controlling for size, a positive relationship is found with ETR. In the study, however, consolidated accounts are taken into account which naturally excludes SMEs from the analysis.

Finally, applying a meta-regression analysis over the period 1975-2012 also including European studies using financial statement data (e.g., Lazar, 2014; Kraft, 2014), Belz et al. (2018) show that the relation between size and ETR is heterogeneous and conflicting. Further, the authors mention that future research should avoid spurious results by paying more attention to a more accurate definition of firm size and ETR.

Our study improves and complements previous literature. We exploit a unique research setting as our results are based on confidential corporate tax return data. Compared to the existing literature relying exclusively on financial statement data, no assumptions need to be made to proxy for the real tax burden and, furthermore, no tax incentives are excluded. Our corporate tax return data contain information, such as application of reduced tax rates, which is not observable in financial statement data. Moreover, they enable 
us to compare the corporate tax burden calculated with financial statement data. Finally, analysing the determinants of SMEs' tax burden, we compare the results with a wide range of companies, including large domestic and large multinational enterprises.

Using 10,321 Belgian firm observations for the tax year 2013, the results show that, on average, domestic SMEs are less engaged in tax avoidance activities compared to large domestic firms and large MNEs, and as a result face a higher effective tax burden. In particular, SMEs face a tax burden that is on average around 1.6 percentage points higher compared with large domestic firms, and 4.8 percentage points higher compared with large MNEs.

The paper is organized as follows. Section 2 gives a brief overview of Belgium's corporate tax system. Section 3 describes the theory and hypotheses. In Section 4, our data are described. Section 5 presents our model, followed by a discussion of the results in Section 6. Finally, Section 7 concludes.

\section{Belgium's Corporate Tax System for Tax Year 2013}

In Belgium, firms can reduce their 'profit before tax' in the financial statement through tax corrections that cause a difference between book income and tax income. The calculation of the tax base on which the statutory tax rate $(33.99 \%)$ or the reduced tax rates $(24.98 \%$ on income up to EUR 25,000, 31.93\% between EUR 25,000 and EUR 90,000, and 35.54\% between EUR 90,000 and EUR 322,500) will be applied, consists of three big steps. In the first step, the taxable profits are calculated, which are the sum of retained earnings, disallowed expenses and dividends. In the second step, taxable profits have to be split according to their origin. This is important because sometimes profits will be exempted due to double tax treaties in order to avoid double taxation. In the third step, firms can use different tax deductions to further reduce their taxable profits. ${ }^{2}$

Belgium - as well as several other EU countries such as Hungary, France or Spain - provides preferential tax incentives to enhance the competitiveness of $\mathrm{SMEs}^{3}$. SMEs account for $99.8 \%$ of all the enterprises in the European Union and are responsible for $67 \%$ of the total employment. Hence, the creation of an attractive business environment for SMEs has become a major goal of the European Commission. Taxation is argued to be an interesting feature of the business environment as it can be directly influenced and controlled through legislation (European Commission, 2015). As a result, preferential tax incentives have been specially granted for SMEs, among which the reduced tax rates were

2 In the following order: non-taxable items (e.g., donations); the participation exemption; the patent income deduction; the notional interest deduction; the deduction of losses carried forward; investment allowances and the deduction of excess notional interest deduction stocks carried forward. The tax deductions cannot lead to a fiscal loss.

3 According to Article 15 of the Belgian Corporation Code (BCC), SMEs are companies that do not exceed more than one of the following criteria in the last and second last book years: annual work force average $=50$, annual turnover $($ excluding VAT $)=$ EUR 7,300,000 and balance sheet total $=$ EUR 3,650,000. However, a company whose annual work force average exceeds 100 is immediately considered a large company. 
by far the most popular. Also, special depreciation schemes, tax allowances and tax credits for SMEs can be found in the European Union (European Commission, 2015; Bergner et al., 2017). In Belgium, firms can be subject to a reduced tax system when they have a taxable income lower than EUR 322,500. In order to benefit from these reduced rates, firms have to meet five additional conditions ${ }^{4}$.

\section{Non-tax Neutrality to SMEs: Theory and Hypotheses}

SMEs, which mostly concentrate their activities on domestic markets, are not in a 'neutral' tax position compared to large and multinational enterprises.

Firstly, because of higher risk and informational barriers, SMEs have limited access to finance compared to large companies. In particular, SMEs have difficulties obtaining bank loans and are often doomed to rely on self-financing for their investments. Moreover, as interest payments are typically tax-deductible and dividends are not, the non-tax neutrality between equity and debt financing favours large companies (Princen, 2012). Secondly, SMEs face relative higher tax compliance costs compared to large enterprises, because these costs are fixed at a certain level and large companies can enjoy economies of scale (Schoonjans et al., 2011). A third aspect is that the lack of expertise in tax law may put SMEs in a more difficult position when optimizing their tax burden. SMEs generally do not have their own in-house tax experts and have to rely on expensive external advice (Nicodème, 2009). These findings lead to hypothesis $H_{1}$ :

$H_{1}$ : Domestic SMEs have greater difficulties optimizing their tax burden compared to domestic large firms, and as a result face a higher effective tax burden.

Also, domestic SMEs are often not in a tax-neutral competitive environment with multinational firms. MNEs have the opportunity to organize their operations across borders in a tax-optimal way. MNEs dispose of tax-avoiding opportunities, which potentially result in a more beneficial effective tax burden compared to domestic firms. In the European Union, corporate tax policies have not converged to the same extent as other elements of the economic integration process between European member states (MS). As a result, corporate tax systems still differ between European MS, meaning that differences in a country's corporate tax system can potentially affect major investment and finance decisions of firms (Desai et al., 2006). Research has already revealed evidence that a country's corporate tax policy is an important driver of location decisions made by multinationals (De Mooij and Ederveen, 2006; Feld and Heckemeyer, 2011; Barrios et al., 2012).

MNEs exploit gaps and mismatches in tax rules between countries to artificially shift profits from high- to low-tax jurisdictions, mainly in the form of transfer pricing and intercompany financing. Complex business models allow them to exploit loopholes

$4 \quad$ (i) The company is not a financial institution; (ii) $50 \%$ or more of the shares are not held by one or more other companies; (iii) the company cannot distribute dividends for an amount exceeding $13 \%$ of the issued share capital of the book year; (iv) the company pays at least a salary of EUR 36,000 to at least one of the managers; (v) the company is not part of a group which owns a coordination centre. 
in a country's corporate tax system. Several studies found that tax avoidance techniques of multinational firms result in a lower tax burden compared to domestic firms (Rego, 2003; Finke, 2013; Egger et al., 2010). Thus, cross-border activities produce a lower tax on mobile capital (European Commission, 2015). This leads to hypothesis $\mathrm{H}_{2}$ :

$\mathrm{H}_{2}$ : Domestic SMEs are excluded from cross-border profit shifting compared to small MNEs (=SMEs with foreign affiliates), and as a result face a higher effective tax burden.

Considering that small domestic firms pay relatively more taxes compared to large domestic firms $\left(H_{1}\right)$ and small multinationals $\left(H_{2}\right)$, it could also be hypothesized that:

$H_{3}$ : Domestic SMEs face a higher effective tax burden compared to large MNEs.

\section{Data}

We were able to obtain corporate tax return data from the Belgian Federal Government for the tax year $2013^{5}$, including all tax reconciliations and attachments. Because they contained little information on financial statement variables, we merged the tax data with the unconsolidated financial statements from the Bel-first database provided by Bureau Van Dijck. We performed the matching based on firms' unique company numbers. Our initial sample consists of 23,308 firm-level observations, obtained by the stratification process of Neyman (1934). We exclude companies that are not obliged to file their annual accounts. Furthermore, we exclude finance, insurance and state-owned companies, because they could be subject to other accounting reports. Also, companies with an accounting loss are removed, because negative tax rates are difficult to interpret (Richardson and Lanis, 2007; Gupta and Newberry, 1997). This leads to a final sample of 10,321 firm observations. More details on the sample selection criteria are provided in Appendix 1.

\section{Model}

To explain the effective tax burden of domestic SMEs compared to other firms, we use regression analysis. The empirical model for the full sample is specified as follows:

$$
(A C C) \text { ETR }_{i}=\beta_{0}+\beta_{1} \text { TAXSCHEME }+\beta_{2} S M E+\beta_{3} S M E^{*} M N E+\text { Controls }+\mu_{i}
$$

\subsection{ETR based on tax return data instead of accounting data}

The effective tax burden ETR is defined as the ratio of the real 'corporate tax liability' according to the tax return data over the financial 'profit before tax'. The numerator reflects the exact amount of tax expenses as filed in the tax return for the tax year 2013. In particular, it is the result of the statutory (reduced) tax rate(s) applied to the corporate tax base which takes into account all available tax measures such as loss carry-forwards, the participation exemption or the notional interest deduction.

$5 \quad$ Financial years ending between 31 December 2012 and 30 December 2013 are included. 
The ratio of a firm's 'total tax liability' to the 'profits before tax' derived from financial statement data is our second dependent variable (ACC)ETR. We include this variable in order to enhance comparability to other literature that can only rely on accounting data, and to highlight possible differences between results based on accounting data and tax return data.

Since tax return data are not publicly available, many studies have to rely on accounting data to proxy for the real tax burden (e.g., Jaafar and Thornton, 2015; Nicodème, 2007). However, these proxies are very rough and subject to several measurement problems (Hanlon, 2003). For Belgium and other countries, the tax expenses as presented in the financial statements could also include tax assessments of former book years. Furthermore, they could account for additional charges such as foreign taxes and contain tax provisions for profit which are subject to disputes (CBN, 2018; Hanlon, 2003). As a result, the tax expenses as presented in the financial statements could contain taxes that are biasing the true ETR of the current tax year.

\subsection{Explaining variables}

TAXSCHEME is a dummy taking the value of 1 if a firm is subject to the full corporate tax rate of $33.99 \%$. SME is a dummy variable with a value of 1 if a firm is classified as an $S M E$ according to Article 15 of the Belgian Companies Code. $M N E$ is a dummy variable with a value of 1 if a firm has a participation of at least $25 \%$ in a foreign subsidiary. It is assumed that the dummy variable $M N E$ captures (aggressive) tax avoidance techniques (e.g., tax havens, transfer pricing) which are not (fully) reflected by the firm's balance sheet characteristics.

Furthermore, we control for several firm-level characteristics such as losses carried forward, the ratio of leverage, financial assets, intangible and tangible fixed assets and earnings before interest and taxes which are considered important determinants of the effective tax burden in the literature (Chen et al., 2010; Rego, 2003; Richardson and Lanis, 2007; Vandenbussche et al., 2006). A summary of all the variable definitions can be found in Appendix 2.

\section{Results and Discussion}

\subsection{Descriptive statistics}

Table 1 presents the effective tax burden faced by SMEs and large firms, both domestic and multinational firms included. The total ETR averages $24.05 \%$, has a median of $27.18 \%$ and is far below the statutory tax rate of $33.99 \%$. The means and medians of the (ACC)ETR are close to the ETRs based on tax return data. According to Buijink et al. (2002), the average (ACC)ETR for Belgian firms equals 21.64\%. However, their sample consisted of consolidated financial statements. Another study in Belgium, carried out by Vandenbussche et al. (2006) finds an average $(A C C) E T R$ of $26 \%$, but losses carried forward were not included. Further, Table 1 shows that MNEs seem to face a lower ETR compared to domestic firms, no matter 
whether they are small or large. This contradicts the findings of the European Commission (2015), in which Belgian MNEs face a higher effective tax rate compared to SMEs when applying the Devereux-Griffith framework (1999).

Table 1 | (ACC)ETR of SMEs and Large Firms

\begin{tabular}{|l|l|c|c|c|c|c|}
\hline \multicolumn{2}{|c|}{} & N & $\begin{array}{c}\text { MEAN ETR } \\
(\%)\end{array}$ & $\begin{array}{c}\text { MEDIAN ETR } \\
(\%)\end{array}$ & $\begin{array}{c}\text { MEAN } \\
(\text { ACC)ETR (\%) }\end{array}$ & $\begin{array}{c}\text { MEDIAN } \\
\text { (ACC)ETR (\%) }\end{array}$ \\
\hline \multirow{3}{*}{ LARGE } & DOMESTIC & 2,287 & 24.30 & 28.90 & 24.44 & 29.11 \\
\cline { 2 - 7 } & MNE & 709 & 17.80 & 16.60 & 18.57 & 17.74 \\
\cline { 2 - 7 } & ALL & 2,996 & 22.77 & 27.03 & 23.03 & 27.49 \\
\hline \multirow{3}{*}{ SME } & DOMESTIC & 7,161 & 24.70 & 27.42 & 24.20 & 27.08 \\
\cline { 2 - 7 } & MNE & 164 & 16.02 & 8.87 & 15.72 & 7.36 \\
\cline { 2 - 7 } & ALL & 7,325 & 24.57 & 27.26 & 24.01 & 26.91 \\
\hline \multirow{2}{*}{ ALL } & & 10,321 & 24.05 & 27.18 & 23.73 & 27.11 \\
\hline
\end{tabular}

Source: Own estimations.

Table 2 presents the descriptive statistics for $S M E S$ and large firms. Around 52\% of the SMEs apply the reduced tax rates (i.e., TAX SCHEME =0), while this is only 5\% for the large companies. Only $2.2 \%$ of the SMEs operate abroad, while this ratio equals $23.7 \%$ for large companies. Furthermore, Table 2 shows that SMEs have more leverage, more profit, have a higher asset mix and have more losses carried forward compared to large firms.

Appendix 3 shows the Pearson correlations between the dependent and independent variables. The correlation matrix denotes that our dependent variable ETR is positively related to the TAX SCHEME and SME dummy variables and negatively to the $M N E$ dummy variable. A high and significant correlation exists between SIZE and SME (-0.742). However, we do not include these variables in the same regression in order to avoid multicollinearity issues. 
Table 2 | Descriptive Statistics of SMEs and Large Firms

\begin{tabular}{|c|c|c|c|c|c|c|}
\hline & & MEAN & SD & $25 \%$ & $50 \%$ & $75 \%$ \\
\hline \multirow[t]{11}{*}{ SME } & $N=7,325$ & & & & & \\
\hline & SIZE & 12.988 & 1.661 & 11.818 & 12.927 & 14.088 \\
\hline & LEV & 0.160 & 0.215 & 0 & 0.052 & 0.259 \\
\hline & FINAR & 0.059 & 0.186 & 0 & 0 & 0.004 \\
\hline & EQRATIO & 0.428 & 0.380 & 0.205 & 0.438 & 0.701 \\
\hline & INTANG & 0.019 & 0.073 & 0 & 0 & 0 \\
\hline & CAPINT & 0.284 & 0.286 & 0.037 & 0.184 & 0.472 \\
\hline & PROF & 0.180 & 0.224 & 0.037 & 0.103 & 0.235 \\
\hline & LOSS & 0.156 & 0.363 & 0 & 0 & 0 \\
\hline & TAX SCHEME & 0.477 & 0.500 & 0 & 0 & 1 \\
\hline & MNE & 0.022 & 0.148 & 0 & 0 & 0 \\
\hline \multirow[t]{11}{*}{ LARGE } & $N=2,996$ & & & & & \\
\hline & SIZE & 17.106 & 1.762 & 15.915 & 16.942 & 18.195 \\
\hline & LEV & 0.106 & 0.172 & 0 & 0.026 & 0.128 \\
\hline & FINAR & 0.148 & 0.274 & 0 & 0.003 & 0.135 \\
\hline & EQRATIO & 0.478 & 0.297 & 0.254 & 0.457 & 0.711 \\
\hline & INTANG & 0.014 & 0.054 & 0 & 0 & 0.003 \\
\hline & CAPINT & 0.159 & 0.220 & 0.008 & 0.063 & 0.216 \\
\hline & PROF & 0.119 & 0.153 & 0.028 & 0.077 & 0.157 \\
\hline & LOSS & 0.058 & 0.234 & 0 & 0 & 0 \\
\hline & TAX SCHEME & 0.950 & 0.219 & 1 & 1 & 1 \\
\hline & MNE & 0.237 & 0.425 & 0 & 0 & 0 \\
\hline
\end{tabular}

Note: SIZE is the natural log of total assets; LEV is the ratio of long-term debts to total assets; FINAR is the ratio of financial assets to total assets; EQRATIO is the ratio of equity to total assets; INTANG is the ratio of intangible fixed assets to total assets; CAPINT is the ratio of tangible fixed assets to total assets; $P R O F$ is the ratio of the earnings before interest and taxes to total assets; LOSS is a dummy with a value of 1 if the firm has losses carried forward and zero otherwise. TAX SCHEME is a dummy variable with a value of 1 if the firm is subject to the full tax scheme. MNE is a dummy variable with a value of 1 when the company has a participation of at least $25 \%$ in a foreign subsidiary.

Source: Own estimations. 


\subsection{Regression results}

Although our summary statistics give some insight into the potential relationship between the different firm types and the ETR, they do not allow us to take adequately into account other covariates that may be correlated with our ETR measures, nor do they allow us to say anything about directions and causality. In order to deal with these issues, we apply multivariate regression analysis. The dependent variable ETR in models (1) to (4) of Table 3 is based on tax return data and (ACC)ETR in models (5) to $(8)$ on accounting data.

In each of the models (1) to (4), we find evidence that firms applying the reduced tax rates $($ TAX SCHEME $=0$ ) have a tax burden that is between 1.9 and 5.7 percentage points lower compared to other firms (at the 1\% significance level). In model (1) of Table 3, MNEs are removed from the sample. The results indicate that domestic SMEs face a statistically higher ETR compared to domestic large firms, which is in line with our Hypothesis $1\left(H_{1}\right)$. However, the findings also show that firms applying the reduced tax rates, which are mainly SMEs, can eliminate the higher effective tax rate through the use of these reduced rates.

In model specifications (2) and (3), we make a sample split on the basis of the $S M E$ dummy. For both subsamples of small and large firms, the $M N E$ dummy has a significant reducing impact on the effective tax burden with 4.1 percentage points and 1.5 percentage points, respectively. These findings confirm Hypothesis $2\left(\mathrm{H}_{2}\right)$. Furthermore, the sample split allows us to verify whether the SIZE variable has an important influence on ETR. The significant negative association between SIZE and the ETR for both the SME and large firm subsamples indicates that larger firms are better able to reduce their corporate effective tax burden. This finding is in line with previous literature relying on the 'political power hypothesis' (e.g., Watts and Zimmerman, 1990) which states that large firms can more easily optimize their tax operations by affecting the political process.

Model (4) of Table 3 presents our main model for the full sample, including an interaction effect between SMEs and MNEs. Domestic SMEs face an ETR that is on average 4.8 percentage points (i.e., $0.016+0.032$ ) higher compared to large MNEs, which is in line with Hypothesis $3\left(H_{3}\right)$. In case the domestic SME would enjoy the reduced tax rates, this would be insufficient to compensate for the higher tax burden. For the full sample, results are again in line with Hypothesis $1\left(H_{1}\right)$, i.e., domestic SMEs face a 1.6 percentage-point higher tax burden compared to domestic large firms. Less conclusive findings are made for the relationship between domestic SMEs and SMEs with foreign affiliates. The sign is in the direction of Hypothesis $2\left(\mathrm{H}_{2}\right)$; however, we are not able to find a significant relationship for the interaction term.

The use of corporate tax return data allows us to adequately determine the effective tax rate of companies. However, most tax research is exclusively built upon accounting data. Models (5) to (8) have the accounting effective tax rate (ACCETR) as the dependent variable and show that we could lose important information compared to tax return data. Having access to accounting data only does not allow to control for the reduced tax rates. 
Table 3 | Regression Results

\begin{tabular}{|c|c|c|c|c|c|c|c|c|}
\hline & (1) & (2) & (3) & (4) & (5) & (6) & (7) & (8) \\
\hline Method & OLS & OLS & OLS & OLS & OLS & OLS & OLS & OLS \\
\hline Dep. Var. & ETR & ETR & ETR & ETR & $(A C C) E T R$ & (ACC)ETR & $(A C C) E T R$ & (ACC)ETR \\
\hline Sample & Domestic & SME & Large & Total & Domestic & SME & Large & Total \\
\hline TAX SCHEME $($ full=1) & $0.019 * * *$ & $0.027^{* * *}$ & $0.057^{* * *}$ & $0.019 * * *$ & - & - & - & - \\
\hline SME & $0.015^{* * *}$ & - & - & $0.016^{* * *}$ & -0.001 & - & - & -0.002 \\
\hline MNE & - & $-0.041^{* * *}$ & $-0.015^{* * *}$ & $-0.032^{* * *}$ & - & $-0.046^{* * *}$ & -0.007 & $-0.031^{* * *}$ \\
\hline$S M E * M N E$ & - & - & - & -0.020 & - & - & - & - \\
\hline CAPINT & $-0.028 * * *$ & $-0.029 * * *$ & 0.007 & $-0.025^{* * *}$ & $-0.019^{* *}$ & $-0.019 *$ & -0.014 & $-0.019 * *$ \\
\hline LEV & $0.024^{*}$ & $0.058^{* * *}$ & $-0.087^{* * *}$ & 0.017 & $0.030^{* *}$ & $0.055^{* * *}$ & $-0.077^{* * *}$ & $0.023^{*}$ \\
\hline INTANG & $0.108^{* * *}$ & $0.073^{* *}$ & $0.259 * * *$ & $0.103 * * *$ & $0.079^{* *}$ & 0.045 & $0.238^{* * *}$ & $0.074^{* *}$ \\
\hline EQRATIO & $-0.062^{* * *}$ & $-0.031^{* * *}$ & $-0.171^{* * *}$ & $-0.068^{* * *}$ & $-0.064 * * *$ & $-0.035^{* * *}$ & $-0.174 * * *$ & $-0.070 * * *$ \\
\hline FINAR & $-0.151^{* * *}$ & $-0.122^{* * *}$ & $-0.109 * * *$ & $-0.153^{* * *}$ & $-0.137^{* * *}$ & $-0.111^{* * *}$ & $-0.125^{* * *}$ & $-0.145^{* * *}$ \\
\hline SIZE & - & $-0.012^{* * *}$ & $-0.015^{* * *}$ & - & - & $-0.005^{* * *}$ & $-0.014^{* * *}$ & - \\
\hline PROF & $0.042^{* *}$ & $0.021^{* *}$ & $0.048^{* * *}$ & $0.047^{* * *}$ & $0.065^{* * *}$ & $0.057^{* *}$ & $0.055^{* *}$ & $0.069 * * *$ \\
\hline LOSS & $-0.171^{* * *}$ & $-0.173^{* * *}$ & $-0.200^{* * *}$ & $-0.173^{* * *}$ & $-0.185^{* * *}$ & $-0.177^{* * *}$ & $-0.220 * * *$ & $-0.186^{* * *}$ \\
\hline Sector dummies & YES & YES & YES & YES & YES & YES & YES & YES \\
\hline Constant & $0.224^{* * *}$ & $0.383^{* * *}$ & $0.568^{* * *}$ & $0.228^{* * *}$ & $0.238^{* * *}$ & $0.277^{* * *}$ & $0.568^{* * *}$ & $0.242^{* * *}$ \\
\hline Observations & 9,448 & 7,325 & 2,996 & 10,321 & 9,448 & 7,325 & 2,996 & 10,321 \\
\hline Adj. $R^{2}(\%)$ & 10.60 & 11.07 & 22.20 & 11.98 & 12.42 & 11.87 & 25.06 & 13.38 \\
\hline F-statistic & 44.91 & 40.56 & 34.16 & 59.37 & 58.54 & 46.78 & 42.55 & 76.54 \\
\hline
\end{tabular}

Note: ETR is defined as the ratio of the corporate tax liability according to the tax return data over the accounting profit before tax;

(ACC)ETR is defined as the ratio of the corporate tax liability according to the financial statements over the accounting profit before tax;

SIZE is the natural log of total assets;

$L E V$ is the ratio of long-term debts to total assets;

FINAR is the ratio of financial assets to total assets;

EQRATIO is the ratio of equity to total assets;

INTANG is the ratio of intangible fixed assets to total assets;

CAPINT is the ratio of tangible fixed assets to total assets;

$P R O F$ is the ratio of the earnings before interest and taxes to total assets;

LOSS is a dummy with a value of 1 if the firm has losses carried forward and zero otherwise.

TAX SCHEME is a dummy variable with a value of 1 if the firm is subject to the full tax scheme.

$M N E$ is a dummy variable with a value of 1 when the company has a participation of at least $25 \%$ in a foreign subsidiary. $S M E$ is a dummy variable which takes the value of 1 when the company is an SME according to Article 15 of the Belgian Corporate Code.

Robust Standard errors are between brackets (using the Huber-White sandwich estimators); ${ }^{* * *} p<0.01 ;{ }^{* *} p<0.05 ;{ }^{*} p<0.1$. All the variables are winsorized at the $1^{\text {st }}$ and $99^{\text {th }}$ percentile.

Source: Own estimations. 
However, not controlling for the reduced tax rates, which is an important determinant of the ETR, could lead to a severe omitted variable bias. Furthermore, the (ACC)ETR is less precise than the ETR based on tax return data. In particular, the results show that the estimated coefficient of the $S M E$ dummy variable is systematically lower than its actual value and becomes insignificant. In the subsample of large firms (7), also the MNE dummy variable loses significance. A possible explanation could be that large and multinational firms face a more complex tax situation, are more likely to be tax-aggressive and scrutinized by the tax administration. As a consequence, those companies might have extra tax assessments of former book years, higher foreign taxes and more provisions for uncertain tax positions in the current year. This would bias the coefficients of large and multinational companies upwards and result in an $(A C C) E T R$ that is higher than the ETR according to the tax return data. As a result, the difference in (ACC)ETR between small and large and domestic and multinational firms could become insignificant. In brief, our findings highlight the importance of tax return data for accurately assessing the corporate tax burden.

\subsection{Robustness tests}

As a first robustness check, we verify in Table 4 whether our results are not driven by group structures ( $c f$. column 1). We insert a dummy variable GROUP which takes the value of 1 if the company belongs to a domestic or multinational group ${ }^{6}$ and zero when the company is independent. It could be argued that domestic groups can, to some extent, use similar tax planning techniques as multinational groups. Group companies are able to shift profits and losses between group members to minimize the tax burden and have more expertise in tax planning compared to independent companies (Beuselinck and Deloof, 2014). The results in column 1 show that belonging to a group does not have a significant influence on the corporate tax burden. Important to mention is that the magnitude and signs of our variables of interest remain unchanged.

As a second robustness check ( $c f$. column 2), we remove the $10 \%$ smallest observations from the sample that are based on the firm's total assets. It could be argued that micro firms are less likely to be engaged in tax planning activities compared to other firms. The results hold and are comparable with model (4) in Table 3.

$6 \quad$ In the Bel-first database, the dummy takes the value of 1 if the company has a $50 \%$ (in)direct participation in a subsidiary and/or can be considered a subsidiary of a parent company which (in) directly owns at least $50 \%$ of the shares in the respective firm. 
Table 4 | Robustness Checks

\begin{tabular}{|l|c|c|}
\hline & $(\mathbf{1})$ & $(\mathbf{2})$ \\
\hline Dependent variable & ETR & ETR \\
\hline Sample & TOTAL & - \\
\hline TAX SCHEME (full = 1) & $0.019^{* * *}$ & $0.015^{* * *}$ \\
\hline SME & $0.014^{* * *}$ & $0.013^{* *}$ \\
\hline MNE & $-0.031^{* * *}$ & $-0.033^{* * *}$ \\
\hline SME*MNE & 0.002 & 0.008 \\
\hline GROUP & -0.008 & - \\
\hline CAPINT & $-0.024^{* *}$ & $-0.024^{* * *}$ \\
\hline LEV & 0.015 & -0.011 \\
\hline INTANG & $0.103^{* * *}$ & $0.109^{* * *}$ \\
\hline EQRATIO & $-0.067^{* * *}$ & $-0.115^{* * *}$ \\
\hline FINAR & $-0.158^{* * *}$ & $-0.144^{* * *}$ \\
\hline PROF & $0.046^{* * *}$ & $0.091^{* * *}$ \\
\hline LOSS & $-0.172^{* * *}$ & $-0.168^{* * *}$ \\
\hline Sector dummies & YES & YES \\
\hline Constant & $0.229^{* * *}$ & $0.251^{* * *}$ \\
\hline Observations & 10,321 & 9,288 \\
\hline Adj. $\mathbf{R}^{\mathbf{2}}$ (\%) & 11.97 & 13.97 \\
\hline F-statistic & 55.52 & 68.65 \\
\hline
\end{tabular}

Note: ETR is defined as the ratio of the corporate tax liability according to the tax return data over the accounting profit before tax;

(ACC)ETR is defined as the ratio of the corporate tax liability according to the financial statements over the accounting profit before tax;

SIZE is the natural log of total assets;

$L E V$ is the ratio of long-term debts to total assets;

FINAR is the ratio of financial assets to total assets;

EQRATIO is the ratio of equity to total assets;

INTANG is the ratio of intangible fixed assets to total assets;

CAPINT is the ratio of tangible fixed assets to total assets;

$P R O F$ is the ratio of the earnings before interest and taxes to total assets;

LOSS is a dummy with a value of 1 if the firm has losses carried forward and zero otherwise.

TAX SCHEME is a dummy variable with a value of 1 if the firm is subject to the full tax scheme.

$M N E$ is a dummy variable with a value of 1 when the company has a participation of at least $25 \%$ in a foreign subsidiary. $S M E$ is a dummy variable which takes the value of 1 when the company is an SME according to Article 15 of the Belgian Corporate Code.

Robust Standard errors are between brackets (using the Huber-White sandwich estimators); ${ }^{* * *} p<0.01 ;{ }^{* *} p<0.05 ;{ }^{*} p<0.1$. All the variables are winsorized at the $1^{\text {st }}$ and $99^{\text {th }}$ percentile.

Source: Own estimations. 


\section{Conclusions}

Drawing on corporate tax return data, we provide new evidence that large domestic firms and large MNEs are better able to reduce their effective tax burden compared to domestic SMEs. In line with our stated hypotheses, the higher ETR of domestic SMEs suggests that these SMEs are not in a tax-neutral position as they face several tax obstacles and are excluded from cross-border shifting.

In particular, domestic SMEs face a tax burden that is on average around 1.6 percentage points higher compared with large domestic firms $\left(H_{1}\right), 4.1$ percentage points higher compared with small multinational firms $\left(\mathrm{H}_{2}\right)$ and 4.8 percentage points higher compared with large MNEs $\left(H_{3}\right)$. Even though (aggressive) tax-avoiding techniques employed by MNEs can only indirectly be measured in this study, the results suggest that the reduced tax rates are especially inadequate to compensate for the bigger tax advantages of operating abroad.

This raises the question if preferential tax incentives for SMEs, which are widespread in the European Union, are the first-best solution to tackle an SME's competitive disadvantage. In line with the studies of Bergner et al. (2017) and Freedman and Crawford (2010), we believe that the removal of tax-related obstacles might be most appropriate to stimulate the growth of SMEs. One of these obstacles relates to the high compliance costs SMEs are facing (Schoonjans et al., 2011). Introducing administrative reliefs (e.g., simplified procedures and tax accounts) could make this compliance less costly. Besides, tackling tax-avoidance techniques of multinational companies should stay a priority within the EU in order to ensure a level playing field for all companies. The implementation of the AntiTax Avoidance Directive (e.g., including interest limitation rules and CFC rules) by the EU member states could be a first step in the right direction (European Commission, 2016b).

Furthermore, in this study we shed more light on the results of the study by the European Commission (2015) which could be interesting for European policy makers. The EC (2015) study states that Belgian SMEs face a lower corporate tax burden compared to large domestic firms and even multinationals. An explanation for the different results in our study is that the corporate tax return data allow us to drop the (strict) assumptions applicable in the Devereux-Griffith model, among which the tax planning activities of MNEs seem to be underestimated in the model. We also show that the results could be biased if they are exclusively built upon accounting data. The tax expenses that are mentioned in the financial statements are blurred by taxes of former book years, foreign taxes and tax provisions and, as a consequence, do not reflect the real ETR of the current tax year. Therefore, we would like to emphasize the use of corporate tax return data to precisely estimate the corporate tax burden. Finally, extending tax return analyses to other European countries which also provide specific SME tax incentives could be a suggestion for future research. 


\section{Appendix 1 | Sample Selection Procedure}

We used a stratified sample of the population of Belgian companies that are subject to corporate income tax. The stratification process is executed on the basis of the 'taxable profits' using the Neyman (1934) method, with exhausting sampling for the most positive and negative results.

\begin{tabular}{|l|r|r|r|c|c|}
\hline Stratum & Upper limit & Lower limit & Firm population & Sampling rate (\%) & Firms in sample \\
\hline $\mathbf{1}$ & $5,978,221,119$ & $3,941,720$ & 1,817 & 100 & 1,817 \\
\hline $\mathbf{2}$ & $3,939,517$ & $1,109,150$ & 3,608 & 50 & 1,804 \\
\hline $\mathbf{3}$ & $1,107,871$ & 306026 & 12,803 & 14 & 1,829 \\
\hline $\mathbf{4}$ & 305,990 & 82,778 & 46,040 & 5 & 2,302 \\
\hline $\mathbf{5}$ & 82,668 & 12,427 & 142,600 & 2 & 2,852 \\
\hline $\mathbf{6}$ & 12,418 & $-46,195$ & 257,430 & 3 & 8,581 \\
\hline $\mathbf{7}$ & $-46,243$ & $-775,250$ & 19,088 & 13 & 2,386 \\
\hline $\mathbf{8}$ & $-783,857$ & $-1,874,015,258$ & 1,737 & 100 & 1,737 \\
\hline Total & & & 485,123 & & 23,308 \\
\hline
\end{tabular}

Source: Authors.

Our initial sample consists of 23,308 companies. To arrive at our final dataset, some corrections had to be made. 


\begin{tabular}{|c|c|}
\hline Initial sample & 23,308 \\
\hline Companies that did not met the required information ${ }^{7}$ & 3,389 \\
\hline \multicolumn{2}{|l|}{ Public utilities (NACE CODE 35-39), financial and insurance companies } \\
\hline $\begin{array}{l}\text { (NACE CODE 64-66), publicly owned companies ( } 84-85 \text { : Public administration and } \\
\text { defence; compulsory social security and Education) }\end{array}$ & 2,034 \\
\hline Firms where Art. 216(2) of the Tax Code was applicable were deleted ${ }^{9}$ & 27 \\
\hline $\begin{array}{l}\text { Companies of which the accounting data from the annual } \\
\text { account were not available according to Bel-first }{ }^{10}\end{array}$ & 184 \\
\hline Companies with two closing dates in the tax year $2013^{11}$ & 8 \\
\hline Companies with an accounting loss in the tax year 2013 & 7,128 \\
\hline Companies with a loss according to tax return data ${ }^{12}$ & 217 \\
\hline Final sample & 10,321 \\
\hline
\end{tabular}

7 Companies involved in bankruptcy proceedings (which have not yet ended), companies that not have to file their annual accounts, such as limited and general partnerships and companies that should have filed their annual accounts for the tax year 2013, but did not.

8 A few NACE codes originating from Bel-first were missing and were completed with NACE codes according to the tax data. Some companies had a zero value for the NACE code and were completed from the National Bank of Belgium's database. Hereby, we deleted 679 extra finance and insurance (NACE CODE 64-66), 12 public utilities (NACE 35-39) and 9 state-owned companies (NACE 84-85).

9 These are companies with social objectives (such as social housing), which are subject to a lower corporate tax rate of $5 \%$.

10 Companies involved in liquidation proceedings or companies that filed an empty or wrong annual account.

11 And it was impossible to find the correct data in Bel-first.

12 These companies have a profit according to their financial statements, but incur a loss in the calculation from the accounting profit before tax to the taxable profits. 
Appendix 2 | Variable Definitions

\begin{tabular}{|c|c|}
\hline Variable & Description \\
\hline ETR & Corporate tax liability according to tax return data / accounting profit before taxes \\
\hline$(A C C) E T R$ & $\begin{array}{l}\text { Corporate tax liability according to the financial statements / accounting profit } \\
\text { before taxes }\end{array}$ \\
\hline TAXSCHEME & $\begin{array}{l}\text { Dummy variable which takes the value of } 1 \text { when the company is subject to the full } \\
\text { tax scheme }(33.99 \%)\end{array}$ \\
\hline MNE & $\begin{array}{l}\text { Dummy variable which takes the value of } 1 \text { when the company has a participation } \\
\text { of at least } 25 \% \text { in one foreign subsidiary }\end{array}$ \\
\hline SME & $\begin{array}{l}\text { Dummy variable which takes the value of } 1 \text { when the company did not exceed more } \\
\text { than one of the following criteria in the last and second last book years: Annual work } \\
\text { force average = 50, Annual turnover (excluding VAT) = EUR 7,300,000 and balance } \\
\text { sheets total = EUR } 3,650,000 \text {. However, a company whose annual work force average } \\
\text { exceeds } 100 \text { is immediately considered a large company. }\end{array}$ \\
\hline INTANG & Intangible fixed assets / total assets \\
\hline CAPINT & Tangible fixed assets / total assets \\
\hline FINAR & Financial assets / total assets \\
\hline EQRATIO & Equity / total assets \\
\hline LEV & Long term debt / total assets \\
\hline PROF & The amount of earnings before interest and taxes (EBIT) / total assets \\
\hline SIZE & Natural Log of total assets \\
\hline INDUSTRY & 14 dummy variables based on the 2-digit NACE-BEL codes \\
\hline LOSS & $\begin{array}{l}\text { Dummy variable with a value of } 1 \text { if there are losses carried forward in the tax year } \\
2013\end{array}$ \\
\hline GROUP & $\begin{array}{l}\text { Dummy variable with a value of } 1 \text { if the company belongs to a domestic or } \\
\text { multinational group according to Bel-first }\end{array}$ \\
\hline
\end{tabular}

Source: Authors. 


\begin{tabular}{|c|c|c|c|c|c|c|c|c|c|c|c|c|c|}
\hline 崩 & 1 & 1 & 1 & 1 & 1 & 1 & 1 & 1 & 1 & 1 & 1 & - & 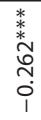 \\
\hline$\sum_{\frac{\pi}{4}}^{\infty}$ & 1 & 1 & 1 & 1 & 1 & 1 & 1 & 1 & 1 & 1 & - & $\begin{array}{l}\text { va } \\
\stackrel{*}{*} \\
\stackrel{m}{0} \\
0\end{array}$ & 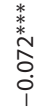 \\
\hline 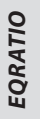 & 1 & 1 & 1 & 1 & 1 & 1 & 1 & 1 & 1 & - & \begin{tabular}{l} 
* \\
\multirow{2}{*}{} \\
$\alpha$ \\
0 \\
0 \\
0
\end{tabular} & \begin{tabular}{l} 
* \\
\multirow{2}{*}{} \\
$\stackrel{0}{0}$ \\
0
\end{tabular} & 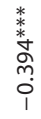 \\
\hline$\underset{\leqslant}{\gtrless}$ & 1 & 1 & 1 & 1 & 1 & 1 & 1 & 1 & - & \begin{tabular}{l}
$*$ \\
\multirow{*}{*}{} \\
$\stackrel{\hat{O}}{0}$ \\
0 \\
$i$
\end{tabular} & \begin{tabular}{l} 
* \\
\multirow{2}{*}{} \\
$\stackrel{0}{0}$ \\
0 \\
$i$ \\
1
\end{tabular} & 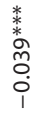 & 。े \\
\hline 岃 & 1 & 1 & 1 & 1 & 1 & 1 & 1 & - & \begin{tabular}{l} 
w \\
\multirow{2}{*}{} \\
$\stackrel{0}{0}$ \\
0
\end{tabular} & $\begin{array}{l}\text { w } \\
\text { w } \\
o ̛ ⿱ \\
0 \\
0 \\
0\end{array}$ & $\begin{array}{l}\text { * } \\
\text { * } \\
0 \\
0 \\
0 \\
0\end{array}$ & $\begin{array}{l}\stackrel{*}{*} \\
\stackrel{2}{2} \\
0 \\
\vdots \\
1\end{array}$ & $\frac{\text { ** }}{\stackrel{*}{\sigma}}$ \\
\hline 衣 & 1 & 1 & 1 & 1 & 1 & 1 & - & 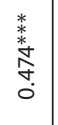 & $\begin{array}{l}\stackrel{*}{*} \\
\stackrel{2}{\hat{N}} \\
0 \\
0 \\
i\end{array}$ & 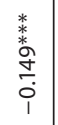 & 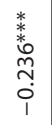 & \begin{tabular}{l}
$\stackrel{*}{*}$ \\
\multirow{2}{*}{} \\
$\stackrel{+}{0}$ \\
$\stackrel{i}{\dot{0}}$
\end{tabular} & $\begin{array}{l}\text { 娄 } \\
\stackrel{0}{0} \\
0\end{array}$ \\
\hline ¿্র & 1 & 1 & 1 & 1 & 1 & - & 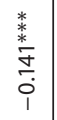 & \begin{tabular}{l}
$*$ \\
$*$ \\
\multirow{2}{*}{} \\
$\stackrel{\leftrightarrow}{0}$ \\
$\stackrel{0}{0}$ \\
1
\end{tabular} & $\begin{array}{l}* \\
\stackrel{\infty}{0} \\
0\end{array}$ & \begin{tabular}{l} 
* \\
$*$ \\
\multirow{0}{*}{} \\
0 \\
$i$ \\
1
\end{tabular} & \begin{tabular}{l}
$\stackrel{*}{*}$ \\
$\stackrel{*}{0}$ \\
6 \\
\hdashline \\
1
\end{tabular} & \begin{tabular}{l} 
* \\
\multirow{2}{*}{} \\
$\stackrel{1}{0}$ \\
0 \\
1
\end{tabular} & 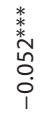 \\
\hline گ్ & 1 & 1 & 1 & 1 & - & 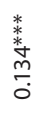 & 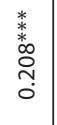 & $\begin{array}{l}\frac{*}{*} \\
\stackrel{*}{2} \\
\stackrel{\sigma}{\sigma}\end{array}$ & $\begin{array}{l}\text { * } \\
\text { * } \\
0 \\
0 \\
0 \\
0\end{array}$ & \begin{tabular}{l} 
* \\
\multirow{2}{*}{} \\
$\stackrel{0}{0}$ \\
0 \\
$\dot{0}$ \\
1
\end{tabular} & \begin{tabular}{l} 
* \\
\multirow{2}{*}{} \\
$\infty$ \\
$\frac{\infty}{0}$ \\
$i$
\end{tabular} & \begin{tabular}{l}
$\stackrel{*}{*}$ \\
$*$ \\
\multirow{2}{*}{} \\
$\hat{0}$ \\
$i$
\end{tabular} & $\frac{\text { 䊑 }}{\frac{m}{0}}$ \\
\hline ফ્ & 1 & 1 & 1 & - & $\begin{array}{l}\text { * } \\
\text { Oे } \\
\stackrel{n}{n} \\
m \\
0 \\
i\end{array}$ & $\frac{\stackrel{*}{*}}{\stackrel{*}{E}}$ & \begin{tabular}{l}
$\frac{*}{*}$ \\
\multirow{2}{J}{} \\
$\stackrel{0}{i}$
\end{tabular} & $\begin{array}{l}8 \\
8 \\
0 \\
1\end{array}$ & $\begin{array}{l}\text { nn } \\
0 \\
\dot{0} \\
1\end{array}$ & 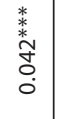 & 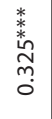 & $\begin{array}{l}\stackrel{*}{*} \\
\stackrel{*}{\sim} \\
\underset{0}{0}\end{array}$ & 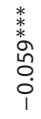 \\
\hline 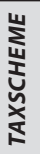 & 1 & 1 & - & $\begin{array}{l}\text { * } \\
\text { * } \\
\stackrel{2}{0} \\
\stackrel{2}{0} \\
i \\
1\end{array}$ & \begin{tabular}{l} 
* \\
* \\
\multirow{0}{*}{} \\
\multirow{0}{*}{}
\end{tabular} & $\begin{array}{l}\text { * } \\
\text { * } \\
\infty \\
\tilde{m} \\
0 \\
0 \\
1\end{array}$ & 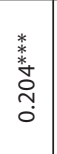 & $\begin{array}{l}\stackrel{*}{*}{ }^{*} \\
\stackrel{m}{0} \\
0\end{array}$ & $\begin{array}{l}\text { 䊝 } \\
\text { 员 } \\
0 \\
0\end{array}$ & $\begin{array}{l}\text { * } \\
\text { * } \\
\infty \\
\widetilde{0} \\
0 \\
i\end{array}$ & $\begin{array}{l}\underset{*}{*} \\
\infty \\
\infty \\
m \\
\\
1\end{array}$ & \begin{tabular}{l} 
* \\
* \\
$\stackrel{9}{+}$ \\
\multirow{0}{0}{} \\
1
\end{tabular} & $\begin{array}{l}\text { w } \\
\text { wo } \\
\text { o } \\
0 \\
0\end{array}$ \\
\hline 芯 & 1 & - & 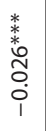 & \begin{tabular}{l}
$*$ \\
$*$ \\
\multirow{2}{*}{} \\
$\infty$ \\
0 \\
0 \\
$i$ \\
1
\end{tabular} & $\begin{array}{l}\stackrel{*}{*} \\
\stackrel{*}{0} \\
\stackrel{0}{0}\end{array}$ & $\begin{array}{l}\text { * } \\
\text { o } \\
\stackrel{m}{o}\end{array}$ & $\begin{array}{l}n \\
\stackrel{0}{0} \\
0 \\
\text { i }\end{array}$ & $\begin{array}{l}\stackrel{2}{0} \\
0 \\
0 \\
1\end{array}$ & $\begin{array}{l}\text { 䊝 } \\
\hat{\Lambda} \\
0 \\
0\end{array}$ & $\begin{array}{l}\stackrel{*}{*} \\
\stackrel{*}{2} \\
\tilde{N} \\
0 \\
0 \\
i\end{array}$ & \begin{tabular}{l} 
* \\
\multirow{2}{*}{} \\
0 \\
0 \\
$i$ \\
1
\end{tabular} & $\begin{array}{l}* \\
* \\
\infty \\
o \\
0 \\
0 \\
1\end{array}$ & 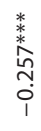 \\
\hline 点 & - & $\begin{array}{l}\text { 絭 } \\
\text { 岁 } \\
\text { 合 }\end{array}$ & $\begin{array}{l}{ }^{*} \\
\stackrel{\infty}{\sigma} \\
\stackrel{0}{0}\end{array}$ & $\begin{array}{l}\text { * } \\
\text { * } \\
\circ \\
\circ \\
0 \\
0 \\
1\end{array}$ & \begin{tabular}{l} 
䊑 \\
\multirow{8}{*}{} \\
0 \\
0
\end{tabular} & 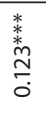 & $\begin{array}{l}\text { oे } \\
\text { o } \\
\text { i }\end{array}$ & 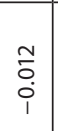 & $\begin{array}{l}\frac{*}{*} \\
\frac{*}{8} \\
8 \\
0\end{array}$ & 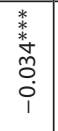 & $\begin{array}{l}\stackrel{*}{*} \\
\stackrel{*}{m} \\
\stackrel{0}{0} \\
1\end{array}$ & \begin{tabular}{l} 
* \\
\multirow{2}{*}{} \\
$\circ$ \\
0 \\
0 \\
1
\end{tabular} & 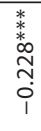 \\
\hline & 点 & 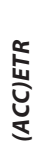 & 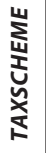 & ফ્ & 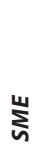 & 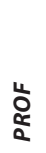 & $\begin{array}{l}\frac{5}{2} \\
\frac{1}{\delta}\end{array}$ & 岃 & 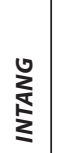 & 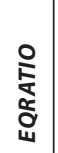 & $\sum_{\frac{\alpha}{k}}^{\infty}$ & $\underset{N}{\mathbf{N}}$ & Цૅ \\
\hline
\end{tabular}

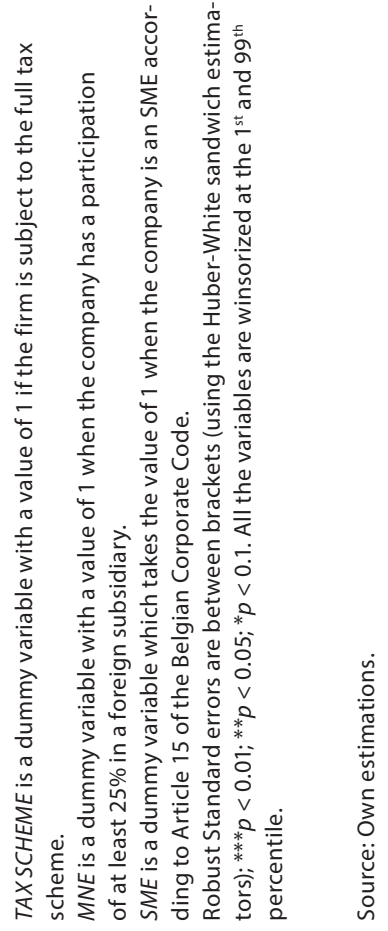

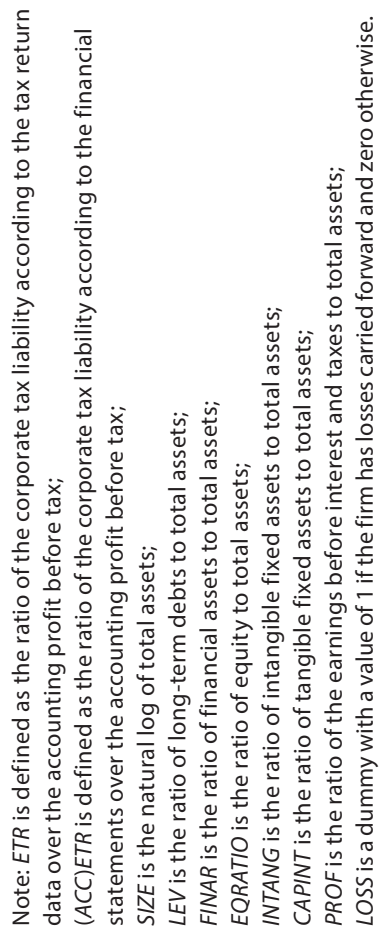




\section{References}

Bergner, S. M., Braütigam, R., Evers, M. T., Spengel, C. (2017). The Use of SME tax Incentives in the European Union. Centre for European Economic Research. ZEW Discussion Paper No. 17-006, https://doi.org/10.2139/ssrn.2910339

Barrios, S., Huizinga, H., Laeven, L., Nicodème, G. (2012). International Taxation and Multinational Firm Location Decisions. Journal of Public Economics, 96(11-12), 946-958, https://doi.org/10.1016/j.jpubeco.2012.06.004

Belz, T., von Hagen, D., Steffens, C. (2018). Taxes and Firm Size: Political Cost or Political Power? University of Mannheim. Working Paper available at http://dx.doi.org/10.2139/ssrn.2697468.

Beuselinck, C., Deloof, M. (2014). Earnings Management in Business Groups: Tax Incentives or Expropriation Concealment. The International Journal of Accounting, 49(1), 27-52, https://doi.org/10.1016/j.intacc.2014.01.008

Buijink, W., Janssen, B., Schols, Y. (2002). Evidence of the Effect of Domicile on Corporate Average Effective Tax Rates in the European Union. Journal of International Accounting, Auditing and Taxation, 11(2), 115-130, https://doi.org/10.1016/S1061-9518(02)00069-1

CBN (2018). CBN-advies 2018/14 - Belastingen. Commissie voor Boekhoudkundige Normen.

Chen, S., Chen, X., Cheng, Q., Shevlin, T. (2010). Are family Firms More Tax Aggressive than Non-Family Firms? Journal of Financial Economics, 95(1), 41-61, https://doi.org/10.1016/j. jfineco.2009.02.003

De Mooij, R. A., Ederveen, S. (2006). What a Difference Does It Make? Understanding the Empirical Literature on Taxation and International Capital Flows. Directorate General Economic and Financial Affairs (DG ECFIN), European Commission. Economic Paper No. 261, available at: http://ec.europa.eu/economy_finance/publications/pages/publication578_en.pdf

Desai, A., Foley, C. F., Hines, J. R. (2006). Taxation and Multinational Activity: New Evidence, New Interpretations. Survey of Current Business, 82(6), 16-22.

Devereux, M. P., Griffith, R. (1999). The Taxation of Discrete Investment Choices. Institute for Fiscal Studies. IFS Working Paper No. 98/16, available at: https://www.ifs.org.uk/wps/wp9816.pdf

Dyreng, S. D., Hanlon, M., Maydew, E. L., Thornock, J. R. (2017). Changes in Corporate Effective Tax Rates over the Past 25 Years. Journal of Financial Economics, 124(3), 441-463, https://doi.org/10.1016/j.jfineco.2017.04.001

Egger, P., Eggert, W., Winner, H. (2010). Saving Taxes Through Foreign Plant Ownership. Journal of International Economics, 81(1), 99-108, https://doi.org/10.1016/j.jinteco.2009.12.004

European Commission (2015). SME Taxation in Europe: An Empirical Study of Applied Corporate Income Taxation for SMEs Compared to Large Enterprises. CIP Programme 186/PP/ENT/ CIP/12/F/S01C24.

European Commission (2016a). Proposal for a Council Directive on a Common Consolidated Corporate Tax Base (CCCTB). Report COM 683, Strasbourg.

European Commission (2016b). Council Directive (EU) 2016/1164 of 12 July 2016. Official Journal of the European Union, Brussels.

Feld, L., Heckemeyer, J. H. (2011). FDI and Taxation: A Meta-Study. Journal of Economic Surveys, 25(2), 233-272, https://doi.org/10.1111/j.1467-6419.2010.00674.x

Finke, K. (2013). Tax Avoidance of German Multinationals and Implications for Tax Revenue: Evidence from a Propensity Score Matching Approach. Centre for European Economic Research (ZEW).

Freedman, J., Crawford, C. (2010). Small Business Taxation. in: Adam et al. (eds.). Dimensions of tax Design: The Mirrlees Review. Oxford University Press for the Institute for Fiscal Studies, 1028-1099. 
Gupta, S., Newberry, K. (1997). Determinants of the Variability in Corporate Effective Tax Rates: Evidence from Longitudinal Data. Journal of Accounting and Public Policy, 16(1), 1-34, https://doi.org/10.1016/S0278-4254(96)00055-5

Hanlon, M. (2003). What Can We Infer about a Firm's Taxable Income from Its Financial Statements? National Tax Journal, 56(4), 831-863, https://doi.org/10.17310/ntj.2003.4.07

Jaafar, A., Thornton, J. (2015). Tax Havens and Effective Tax Rates: An Analysis of Private versus Public European Firms. The International Journal of Accounting, 50(4), 435-457, https://doi.org/10.1016/j.intacc.2015.10.005

Janssen, B. (2005). Corporate Effective Tax Rates in the Netherlands. De Economist, 153(1), 47-66. https://doi.org/10.1007/s10645-004-7127-y

Kraft, A. (2014). What Really Affects German Firms' Effective Tax Rate? International Journal of Financial Research, 5(3), 1-19, http://dx.doi.org/10.5430/ijfr.v5n3p1

Lazar, S. (2014). Determinants of the Variability of Corporate Effective Tax Rates: Evidence from Romanian Listed Companies. Emerging Markets Finance and Trade, 50(4), 113-131, https://doi.org/10.2753/REE1540-496X5004S4007

Neyman, J. (1934). On the Two Different Aspects of the Representative Method: The Method of Stratified Sampling and the Method of Purposive Selection. Journal of the Royal Statistical Society, 97(4), 558-625, https://doi.org/10.2307/2342192

Nicodème, G. (2007). Do Larger Companies Have Lower Effective Corporate Tax Rates? A European Survey. Centre Emile Bernheim. CEB Working Paper No. 7/001

Nicodème, G. (2009). Corporate Income Tax and Economic Distortions. European Commission. Taxation Paper No.15, available at: https://ec.europa.eu/taxation_customs/sites/ taxation/files/resources/documents/taxation/gen_info/economic_analysis/tax_papers/ taxation_paper_15_en.pdf

OECD (2015). Taxation of SMEs in OECD and G20 Countries. Paris: Organization for Economic Cooperation and Development, https://doi.org/10.1787/9789264243507-en

Onofrei, M., Vintila, G., Gherghina, S. C., Paunescu, R. A., Oprea, F. (2018). Do Firm Characteristics Influence Effective Corporate Tax Rate? Empirical Evidence from a Panel of Former Communist Eastern European Markets. Transformations in Business \& Economics, 17(2B), 622-639.

Princen, S. (2012). Taxes do affect corporate financing decisions: the case of Belgian ACE. Catholic University of Louvain (UCL). CESifo Working Paper No. 3713, available at: https://ssrn.com/ abstract $=1992330$

Rego, S. O. (2003). Tax-Avoidance Activities of U.S. Multinational Corporations. Contemporary Accounting Research, 20(4), 805-833, https://doi.org/10.1506/VANN-B7UB-GMFA-9E6W

Richardson, G., Lanis, R. (2007). Determinants of the Variability in Corporate Effective Tax Rates and Tax Reform: Evidence from Australia. Journal of Accounting and Public Policy, 26(6), 689-704, https://doi.org/10.1016/j.jaccpubpol.2007.10.003

Schoonjans, B., Van Cauwenberge, P., Reekmans, C., Simoens, G. (2011). A Survey of tax Compliance Costs of Flemish SMEs: Magnitude and Determinants. Environment and Planning C-Government and Policy, 29(4), 605-621, https://doi.org/10.1068/c10177b

Vandenbussche, H., Crabbé, K., Janssen, B. (2006). is there Regional Tax Competition? Firm Level Evidence for Belgium. De Economist, 153(3), 257-276. https://doi.org/10.1007/ s10645-005-1988-6

Watts, R. L, Zimmerman, J. L. (1990). Positive Accounting Theory: A Ten Year Perspective. The Accounting Review, 65(1), 131-156. 